\title{
Sliding wear behaviour of steel carburized using $\mathrm{Na}_{2} \mathrm{CO}_{3}-\mathrm{NaCl}$
}

\author{
Willey Y. H. Liew ${ }^{\text {a }}$, Jester L.J. Ling, Nancy J. Siambun \\ Faculty of Engineering, Universiti Malaysia Sabah, Jalan UMS, 88400 Kota Kinabalu, Sabah, Malaysia
}

\begin{abstract}
Experiments have been carried out to investigate the effect of carburization process on the sliding wear resistance of mild steel. The carburization process was conducted in carbonate salts mixtures of $\mathrm{Na}_{2} \mathrm{CO}_{3}-\mathrm{NaCl}$. Carburization followed by water quenching resulted in the formation of martensite with a hardness of $900 \mathrm{HV}$ in the subsurface, up to the depth of $400 \mu \mathrm{m}$. This hardness value was substantially higher than the non-carburized steel which had a hardness of $520 \mathrm{HV}$. In the initial stage of sliding in air, abrasive wear and cluster of fine cavities due to adhesion were formed. This was followed by the formation of large-scale fracture at the cavities. The high hardness of the carburized steel reduced the severity of adhesive wear and thus the tendency of the worn surface to fracture.
\end{abstract}

\section{Introduction}

Carburization processes, involve the intentional diffusion of carbon into the subsurface of iron-based alloys at high temperature, are widely used to enhance the wear resistance of mild steel. The carbon rich layer at the subsurface will transform to other microstructure (such as martensite and bainite) depending on the rate of cooling used after the carburization process. Zhang et al. [1] used alcohol and kerosene as carburizer to produce $2.5 \mathrm{~mm}$ thick of bainite and martensite on the subsurface of steel specimens. The bainitic steel is produced by immerging the carburized specimens into a salt bath at $230^{\circ} \mathrm{C}$ for 48 hours before being air cooled to room temperature. Despite having lower hardness, it exhibited higher wear resistance than the martensitic steel produced by rapid cooling after the carburization process. This superior wear resistance of the bainitic steel could be attributed to (i) the high strength and toughness of the bainitic microstructure, (ii) the effectiveness of the carbon enriched film-like austenite formed between the ferrite in preventing crack propagation and (iii) the formation of extremely fine and hard ferrite-phase microstructure at the surface of the bainitic microstructure during sliding. Izciler and Tabur [2] and Ulutan et al. [3] reported that the formation of martensitic microstructure in the carburization process resulted in an increase in the abrasive wear resistance of steel. Bensely et al. [4] found that deep cryogenic treatment applied to the carburized steel after quenching resulted in higher conversion of austenite to martensite and induced precipitation of finer carbides, and thus an increased hardness and wear resistance.
We had demonstrated that the electro-carburization process utilizing non-toxic $\mathrm{Na}_{2} \mathrm{CO}_{3}-\mathrm{NaCl}$ carbonate salts mixture as the electrolyte was effective in enhancing the wear resistance of mild steel under reciprocating sliding condition [5]. The carburized layer, rich in retained austenite on the surface and dominated by martensite in the subsurface, increased the load carrying capacity, and adhesive and abrasive wear resistance of the steel. The superior wear resistance of the martensite, as compared to the austenite, could be attributed to its high cracking and adhesive wear resistance owing to its high hardness and tendency to form oxides. This paper reports the study carried out to investigate the effect of this carburization process on the sliding wear resistance of mild steel.

\section{Experimental}

\subsection{Carburization process}

Fig. 1 shows the set up of the carburization process. It had a retort fabricated using a 316 stainless steel tube. Gas inlet and outlet pipes which continuously supplied $\mathrm{CO}_{2}$ into the sealed retort were also welded on to the lid. The central body of the stainless steel retort was placed in the middle of the furnace (hottest zone) and alumina wool was placed on top of the furnace to minimize heat losses. A crucible of alumina or stainless steel filled with carbonate salts was placed in the middle of the retort on a stainless steel stand before the lid was secured to the retort flange. The mild steel specimens were immersed in the molten salt.

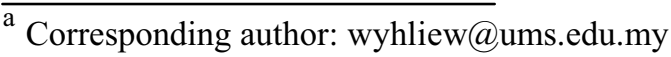


During the carburization process, the temperature of the salt was maintained at $860^{\circ} \pm 10^{\circ} \mathrm{C}$ and the voltage was set to $4.5 \mathrm{~V}$. The temperature of the $\mathrm{Na}_{2} \mathrm{CO}_{3}-\mathrm{NaCl}$ molten salt inside the crucible was measured at various location using several thermometers. Whereas the gas outlet pipe was connected to a dreschel bottle containing mineral oil to prevent the ingress of air to the system.

The $\mathrm{CO}_{2}$ gas supplied into the furnace above the molten salt bath was the carbon source in the proposed electro-carburization process. When an external voltage was applied through the electrodes, the carbonate ions $\left(\mathrm{CO}_{3}^{2-}\right)$ decomposed into carbon atoms and oxide ions $\left(\mathrm{O}^{2-}\right)$ at the cathode (mild steel) according to reaction 1. The carbon atoms produced then diffused into the mild steel. The $\mathrm{O}^{2-}$ ions would either react with the $\mathrm{CO}_{2}$ at the molten salt/gas interface to reform the $\mathrm{CO}_{3}^{2-}$ ion (reaction 2), or transport to, and discharge at the stainless steel plate as $\mathrm{O}_{2}$ gas (reaction 3 ).

$$
\begin{aligned}
& \mathrm{CO}_{3}^{2-}+\mathrm{Fe}+4 \mathrm{e} \Rightarrow \mathrm{C}-\mathrm{Fe}+3 \mathrm{O}^{2-} \\
& \mathrm{O}^{2-}+\mathrm{CO}_{2} \Rightarrow \mathrm{CO}_{3}^{2-} \\
& 2 \mathrm{O}^{2-} \Rightarrow \mathrm{O}_{2}+4 \mathrm{e}
\end{aligned}
$$

reaction 1

reaction 2

reaction 3

where $\mathrm{C}-\mathrm{Fe}$ represents the carbon dissolved in the steel cathode.

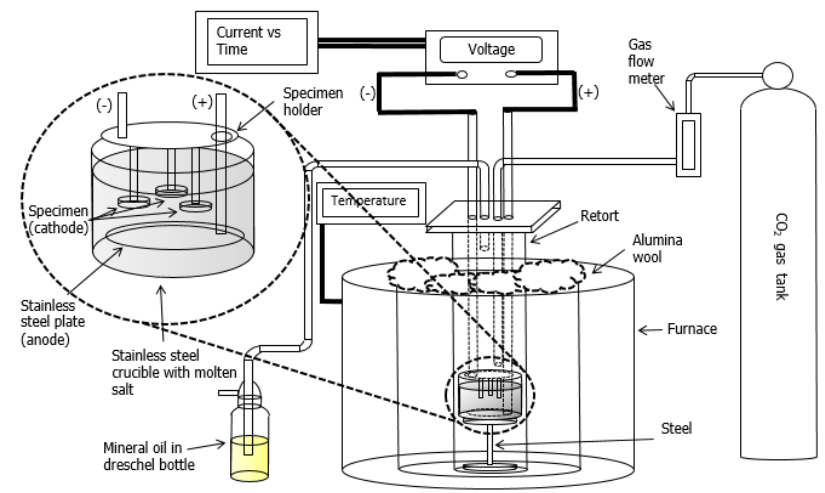

Figure 1. Set up of the carburization process.

\subsection{Materials}

Uncoated cemented carbide balls (6wt \% Co and 94\% WC; grade ISO K10) with a hardness $1600 \mathrm{HV}$ and diameter of $6 \mathrm{~mm}$ were used to slide on the noncarburized and carburized mild steel discs. 2 types of carburized mild steel were used. They were (i) steel carburized at $860^{\circ} \mathrm{C}$ for 1 hour followed by quenching in water (referred as $\mathrm{Cl}$ specimen) and (ii) the noncarburized steel (referred as NC specimen). The NC specimens were produced by heating the specimens at $860^{\circ} \mathrm{C}$ in a furnace, followed by quenching. The mild steel had a nominal chemical compositions of $0.2 \mathrm{wt} . \%$ C, 0.19wt.\% Si, 0.60 wt.\% Mn, 0.014wt.\% P and 0.018 wt. $\%$ S, balance Fe.

\subsection{Sliding tests}

The frictional and wear behaviour of the non-carburized and carburized steel was investigated using a Ducom TR20EV-M3 ball-on-disc tester. The steel specimens were carburized at $860^{\circ} \mathrm{C}$ for 1 hour followed by quenching in water. Tests were carried out at $10 \mathrm{~m} / \mathrm{min}$ and different normal loads of $10,15,30,50$ and $90 \mathrm{~N}$ for a sliding distance of $100 \mathrm{~m}$ in ambient air and vacuum $(1 \times 10-5$ $\mathrm{Pa})$. The coefficient of friction was continuously measured throughout the tests by a load cell. The morphology of the worn surface was examined using a scanning electron microscopy (SEM).

\section{Results and discussion}

\subsection{Hardness measurement}

Fig. 2 shows the variation of the hardness of the subsurface of the $\mathrm{C} 1$ specimen. It had a peak hardness of $910 \mathrm{HV}$ at $45-150 \mu \mathrm{m}$ and a case depth of $450 \mu \mathrm{m}$. Towards the core, the hardness decreased significantly to $520 \mathrm{HV}$, the hardness of the non-carburized steel.

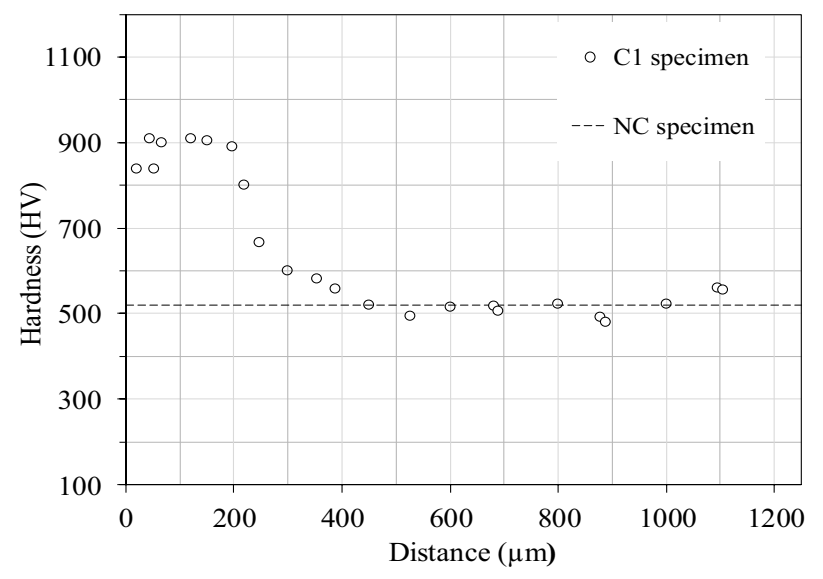

Figure 2. Variation of the subsurface hardness of the carburized and non-carburized steel

\subsection{Microstructure of the carburized steel}

The contaminant on the surface of the $\mathrm{C} 1$ specimen was removed by slight polishing using $1 \mu \mathrm{m}$ size diamond paste before they were etched with nital to unveil the microstructure on the surfaces. Examination of the etched surfaces using an optical microscope showed that the surfaces the specimens had both martensite and retained austenite surrounded by grain boundaries (fig. 3(a)). XRD analysis on the slightly polished surface produced peaks at $2 \theta=44.9^{\circ}, 50.8^{\circ}, 65.1^{\circ}$ and $82.2^{\circ}$ (fig. 4). The peaks at $2 \theta=50.8^{\circ}$ showed that the white grains were retained austenite. The presence of the peaks at $2 \theta=$ $44.9^{\circ}, 65.1^{\circ}$ and $82.2^{\circ}$ indicated that the dark grains were bcc martensite [6-8]. Towards the core, the amount of austenite reduced while the amount of martensite increased. The subsurface at $100 \mu \mathrm{m}$ beneath the original surface with the highest hardness value was dominated by 
martensite with no grain boundaries (fig. 3(b)). This observation was consistent with the XRD results which showed the absence of the austenite peak.

(a)

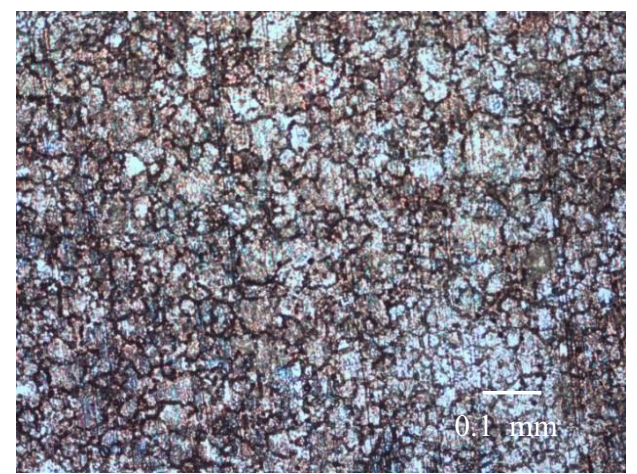

(b)

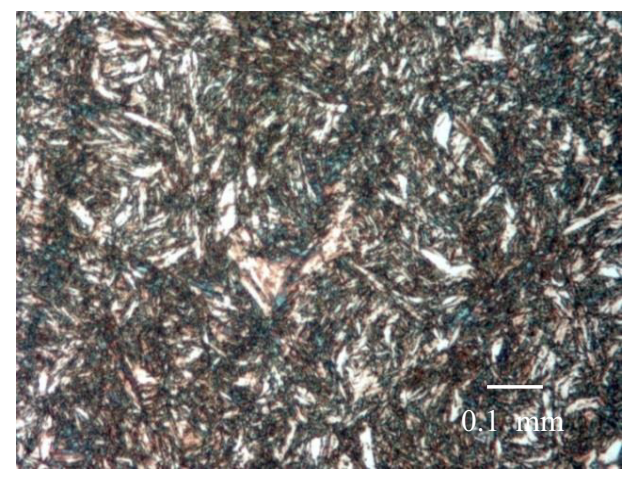

Figure 3. The microstructure at the surface and subsurface of the $\mathrm{C} 1$ specimen. (a) Grain boundaries, and austenite and martensite grains were evident on the surface (b) At the subsurface $100 \mu \mathrm{m}$ beneath the surface, the microstructure was dominated by martensite.

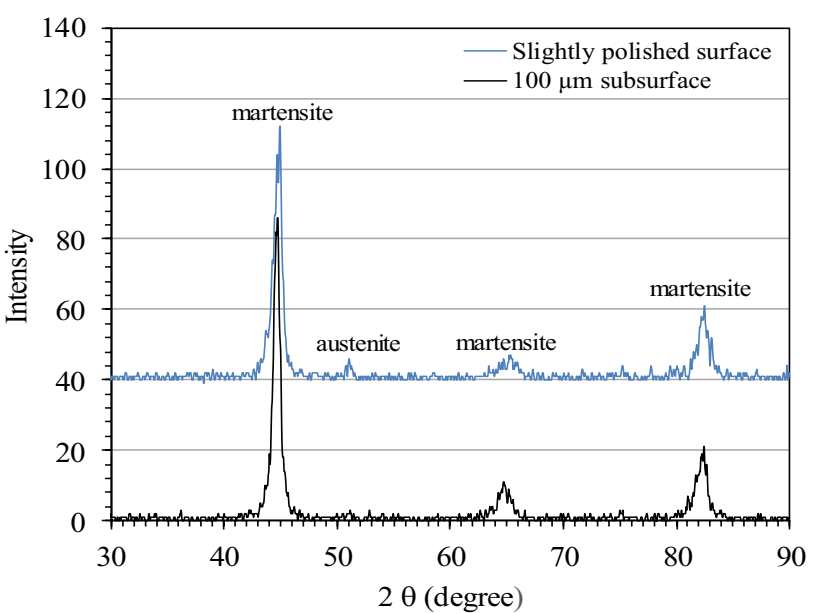

Figure 4. XRD analysis on the surface and sub-surface of the C1 specimen

\subsection{Coefficient of friction}

Figs. 5-8 show the variation of the COF (coefficient of friction) with sliding distance for the $\mathrm{C} 1$ and $\mathrm{NC}$ specimens in air and vacuum at various normal loads. A notable feature of the results obtained in air is the sharp increase followed by a rapid drop in the COF to a low prevailing steady-state value in the initial stage of sliding. This reflects the nature of the running-in process. During the running-in process, plastic deformation takes place on the subsurface results in an increase in the hardness of the material. Once the hardness reaches to a critical value to support a lubricant film, the friction coefficient drops to a low prevailing steady-state value. In vacuum, no oxide film was form after the running-in process. Therefore, an abrupt drop in COF either did not take place or was not evident. In sliding $\mathrm{NC}$ and $\mathrm{C} 1$ specimens at 10, 15 and $30 \mathrm{~N}$, the COF produced in air was much lower than that produced in vacuum throughout the entire test duration (fig. 5). In sliding $\mathrm{NC}$ specimen at $50 \mathrm{~N}$ in air, a low prevailing COF (at least 0.1 lower than that in vacuum) was obtained in the initial stage of sliding. A marked increase in the COF was observed at the distance of 550 $\mathrm{m}$. At the distance of between 550-1000 m, the value of the COF in air and vacuum was approximately the same and the COF in air showed larger fluctuations (fig. 6). The same phenomenon also occurred at $90 \mathrm{~N}$. The tests conducted on the $\mathrm{C} 1$ specimens at $50 \mathrm{~N}$ in air produced either a low prevailing COF throughout the entire test duration or a gradually increased COF (figure 7) or a sudden increase in the COF to the vacuum value (similar to that observed in the NC tests). All tests conducted at $90 \mathrm{~N}$ produced a sudden increase in the value and fluctuation of the COF (fig. 8), similar to that observed in the sliding of the NC specimen (fig. 6).

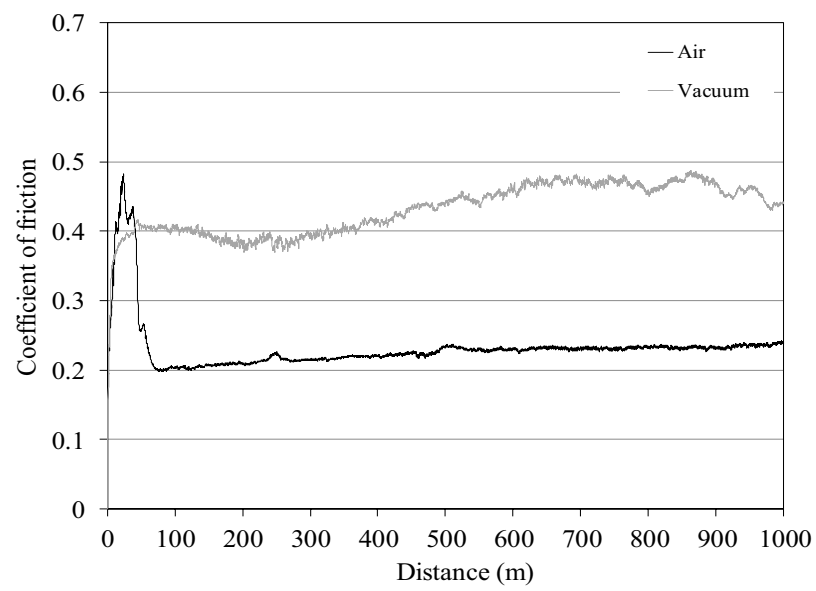

Figure 5. Variation of the coefficient of friction during sliding of $\mathrm{C} 1$ specimen at $30 \mathrm{~N}$.

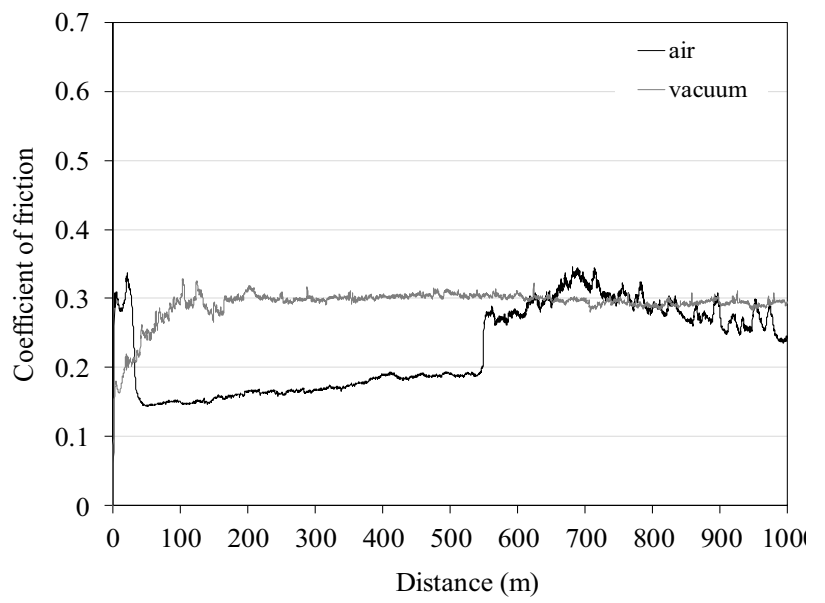

Figure 6. Variation of the coefficient of friction during sliding of $\mathrm{NC}$ specimen at $50 \mathrm{~N}$. 


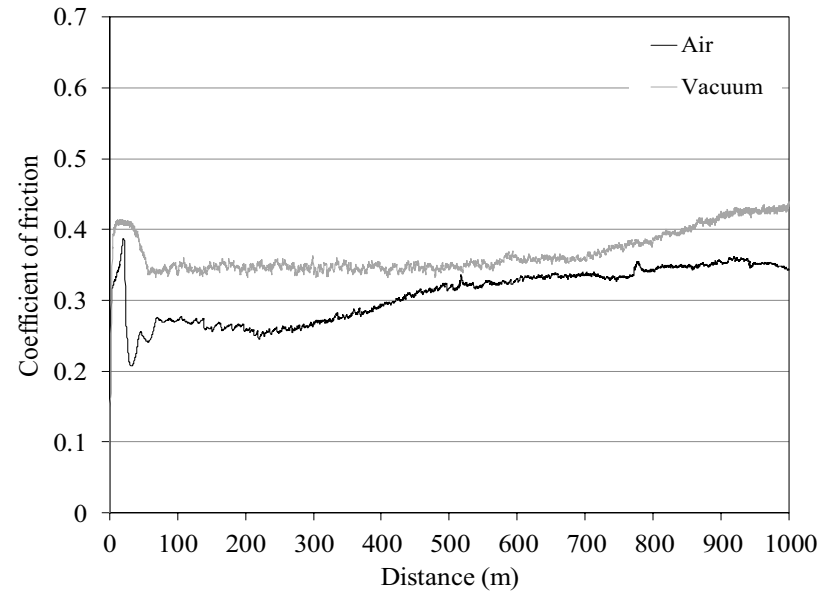

Figure 7. Variation of the coefficient of friction during sliding of $\mathrm{C} 1$ specimen at $50 \mathrm{~N}$.

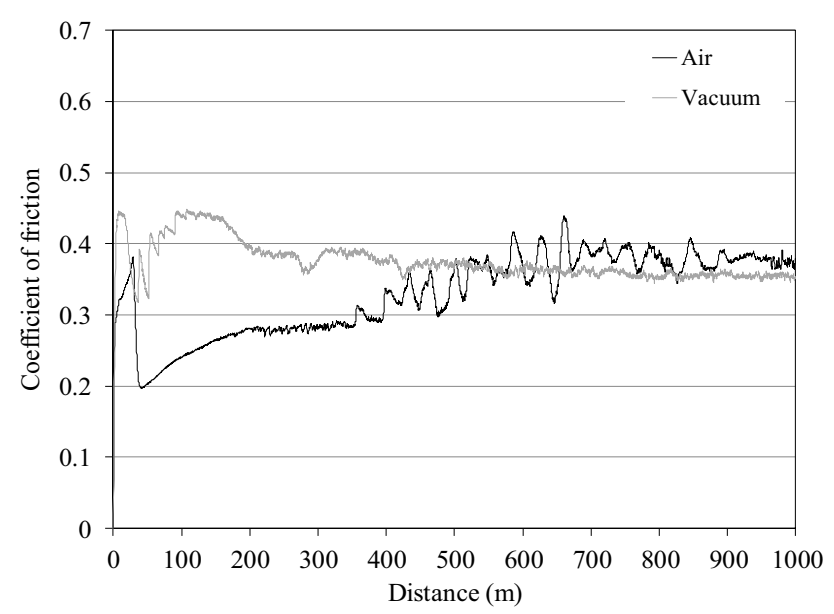

Figure 8. Variation of the coefficient of friction during sliding of $\mathrm{C} 1$ specimen at $90 \mathrm{~N}$.

\subsection{Morphology of the worn surface}

The worn surfaces of $\mathrm{C} 1$ specimen after sliding at 10 and 15 and $30 \mathrm{~N}$ at $10 \mathrm{~m} / \mathrm{min}$ in air had cavities due to the ploughing action of the debris (fig. 9(a)). This indicated that the dominant wear mechanism was abrasive wear. The NC specimen which had a lower hardness was subjected to a lower degree of abrasive wear but to a more severe adhesive wear as can be seen in fig. 9(b).

In the early stage of sliding of the NC specimen at 50 and $90 \mathrm{~N}$ using the speed of $10 \mathrm{~m} / \mathrm{min}$ in air, grooves indicating of abrasive wear and clusters of fine cavities with the diameter of between 5-20 $\mu \mathrm{m}$ were formed on the worn surface (fig. 10). Formation of the fine cavities was due to welding and breaking of adhesive junctions. Such wear mechanism produced fine debris. Examination of the worn surface using the EDXelement-mapping showed that the cavities had much lower concentration of $\mathrm{O}$ element as compared to the groove surface (fig. 11). EDX examination showed that oxygen content in the groove surface was between 27.2$30.2 \mathrm{wt} \%$. Whereas, the cavities had oxygen content of less than $1.0 \mathrm{wt} \%$. Samples of the EDX results are shown in Table 1. This showed that the fine cavities formed on the worn surface were too small to make contact with the carbide ball in the subsequent sliding events to produce sufficient heat for high degree of oxidation to take place. The cavities would then merge to form a larger scale of nascent surface. Once the cavities were large enough to make contact with the carbide ball, severe adhesion between the contact surfaces occurred resulting in high frictional force. High frictional traction at the nascent contact surface caused fracture to take place (fig. 12(a)) and hence the release of flake-like delamination debris from the surface. Other observations further supported the hypothesis that the fracture was initiated at the fine cavities were (i) the distance between the clusters of the fine cavities was almost the same as that between the fractured surface, and (ii) the formation of fracture led to the diminish of the fine cavities. Due to a large amount of oxide film removed by fracture, the frictional condition and thus the COF became similar to that in vacuum which wear was dominated by fracture.

In the sliding of $\mathrm{C} 1$ specimen at $50 \mathrm{~N}$, while clusters of fine cavities were generated, the severity of the adhesive wear was less than those observed on the NC specimen and they did not always develop into fracture. Only at the load of $90 \mathrm{~N}$ had caused fracture to take place in all tests which was reflected by the sudden increase in the frictional force (fig. 8). The size of the fracture surface was less as compared to that formed on the NC specimen (compare fig. 12 (a) and (b)). It could be concluded that the increase in the hardness brought about by the carburization process resulted in a lower degree of adhesive wear, making clusters of nascent fine cavities less likely to form. This in turn reduced the tendency of the worn surface to fracture.
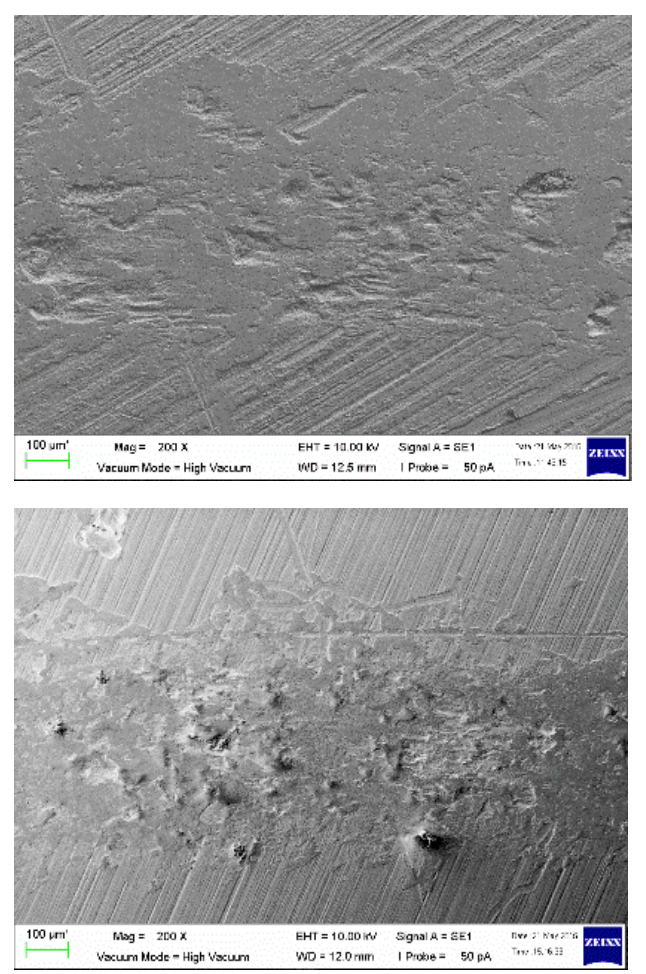

Figure 9. SEM images of the worn surfaces of the (a) $\mathrm{C} 1$ and (b) $\mathrm{NC}$ specimens after sliding for $100 \mathrm{~m}$ at $15 \mathrm{~N}$ in air. 


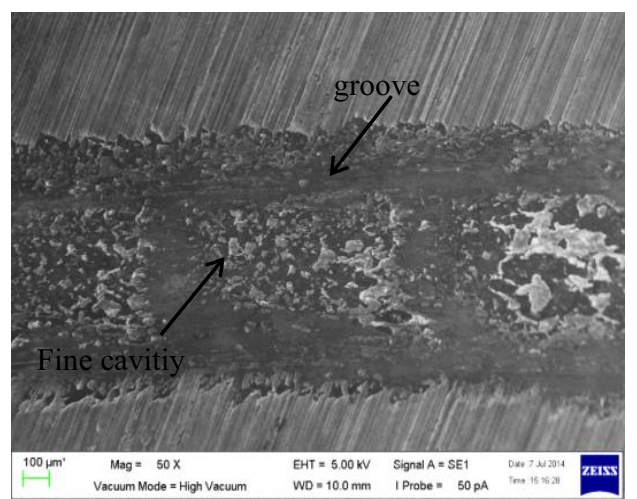

Figure 10. Worn surface of the $\mathrm{NC}$ steel in the initial stage sliding at $90 \mathrm{~N}$ in air. The worn surface consisted of clusters of fine cavities and enlarged cavities.

(a)

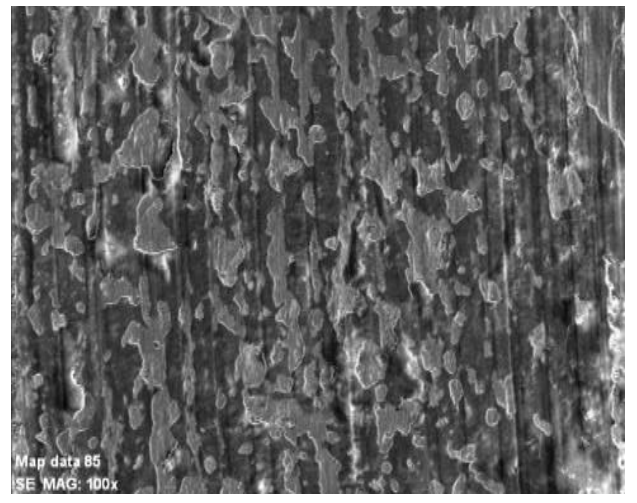

(b)

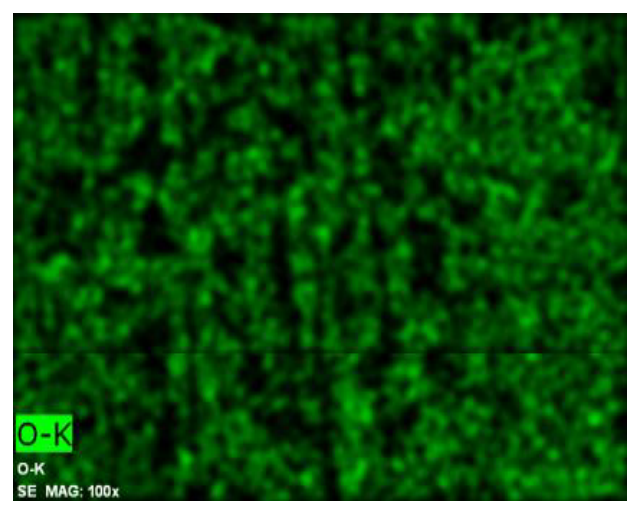

Figure 11. EDX-element-mappings of the worn surface of the NC which consist of numerous fine cavities. The cavities had lower concentration of $\mathrm{O}$ element.

Table 1. EDX analysis on the groove surface and fine cavities.

\begin{tabular}{|l|l|l|}
\hline Element & $\begin{array}{l}\text { norm. [wt.\%] at } \\
\text { the groove surface }\end{array}$ & $\begin{array}{l}\text { norm. [wt.\%] at } \\
\text { the fine cavities }\end{array}$ \\
\hline Carbon & 3.67 & 5.63 \\
\hline Oxygen & 0.79 & 28.91 \\
\hline Iron & 94.56 & 62.53 \\
\hline Sulfur & 0.00 & 0.00 \\
\hline Phosphorus & 0.00 & 0.00 \\
\hline Silicon & 0.15 & 2.30 \\
\hline Manganese & 0.83 & 0.63 \\
\hline
\end{tabular}

\section{Conclusions}

Experiments have been carried out to investigate the effect of carburization process utilizing $\mathrm{Na}_{2} \mathrm{CO}_{3}-\mathrm{NaCl}$ as the electrolyte on the microstructure and the sliding wear behaviour of mild steel. It resulted in an increased hardness of $900 \mathrm{HV}$ in the subsurface, up to the depth of $400 \mu \mathrm{m}$. This hardness value was substantially higher than the non-carburized steel which had a hardness of $520 \mathrm{HV}$. The surfaces of the specimens had both martensite and retained austenite surrounded by grain boundaries. Towards the core, the amount of austenite reduced while the amount of martensite increased. In the initial stage of sliding in air, abrasive wear and cluster of fine cavities due to adhesion were formed. The five cavities acted as preference sites for the formation of largescale fracture. The high hardness of the carburized steel reduced the severity of adhesive wear and thus the tendency of the worn surface to fracture.

(a)

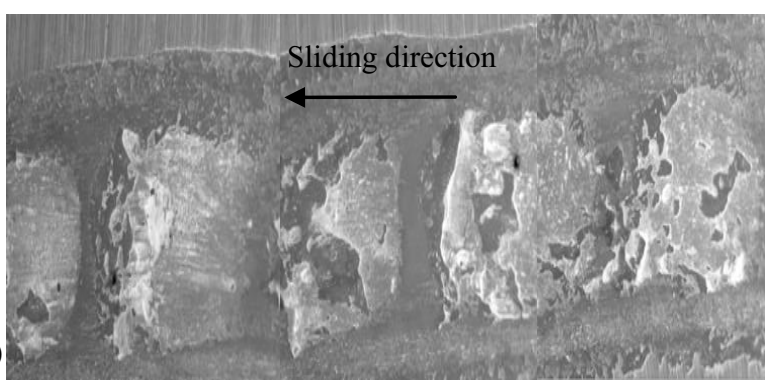

(b)

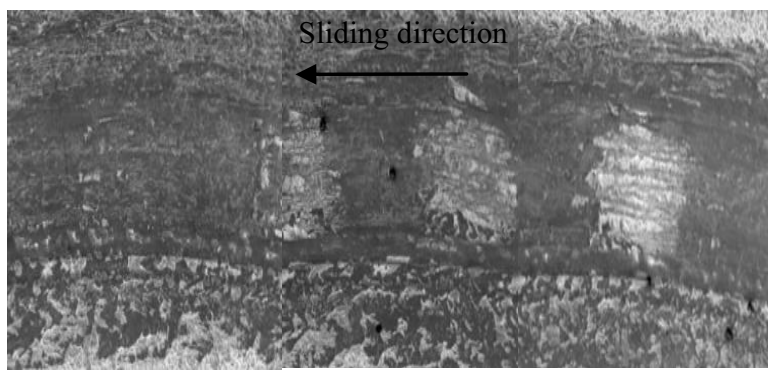

Figure 12. SEM image of the worn surface of the (a) $\mathrm{NC}$ and (b) $\mathrm{C} 1$ specimens after sliding for $100 \mathrm{~m}$ at $90 \mathrm{~N}$ in air.

\section{References}

1. P. Zhang, F.C. Zhang, Z.G. Yan, T.S. Wang, L.H. Qian, "Wear property of low-temperature bainite in the surface layer of a carburized low carbon steel," Wear 271, pp. 697704 (2011)

2. M. Izciler and M. Tabur, "Abrasive wear behavior of different case depth gas carburized AISI 8620 gear steel," Wear 260, pp. 90-98 (2006).

3. M. Ulutan, O. N. Celik, H. Gasan and U. Er, "Effect of Different Surface Treatment Methods on the Friction and Wear Behavior of AISI 4140 Steel," J. Mater. Sci. Technol. 26, pp. 251-257 (2010).

4. A. Bensely, A. Prabhakaran, D. Mohan Lal and G. Nagarajan, "Enhancing the wear resistance of case carburized steel (En 353) by cryogenic treatment," Cryogenics 45, pp.747-754 (2006).

5. Willey Y. H. Liew, Roonie Protasius, Jester L.J. Ling, Nancy J. Siambun and Noor-Ajian Mohd-Lair, "Reciprocating wear behavior of mild steel carburized using $\mathrm{Na}_{2} \mathrm{CO}_{3}-\mathrm{NaCl}$," Tribology International 95, pp. 406418 (2016). 
6. D. Frölich, B. Magyar, B. Sauer, P. Mayer, B. Kirsch, J.C. Aurich, R. Skorupski, M. Smaga, T. Beck, D. Eifler, "Investigation of wear resistance of dry and cryogenic turned metastable austenitic steel shafts and dry turned and ground carburized steel shafts in the radial shaft seal ring system," Wear 328-329, pp. 123-131 (2015).

7. J.R. Tolchard, A. Somme, J.K. Solberg, K.G. Solheim, "On the measurement of austenite in supermartensitic stainless steel by X-ray diffraction," Materials Characterization 99, pp. 238-242 (2015).

8. R. Bhambroo, S. Roychowdhury, V. Kain, V.S. Raja, "Effect of reverted austenite on mechanical properties of precipitation hardenable 17-4 stainless steel," Materials Science \& Engineering A 568, pp. 127-133 (2013). 